\title{
A doença na literatura infanto-juvenil - análise de quatro obras contemporâneas
}

\author{
Illness in the literature for children and youngsters - \\ analysis of four contemporary works
}

\author{
Rosa Maria Hessel Silveira* \\ BRUNA ROCHA SILVEIRA*
}

Resumo: Na sociedade ocidental contemporânea, a doença habita o rol dos assuntos socialmente proibidos. $\mathrm{O}$ tema se apresenta como um tabu em função dos sentidos que atribuímos às doenças e aos doentes. Focalizando a literatura infanto-juvenil, perguntamo-nos como as doenças apareceriam em tal literatura. Nesse trabalho, nos debruçamos sobre essa temática, analisando quatro obras literárias infanto-juvenis disponíveis no mercado brasileiro, que trazem a doença como fio condutor da narrativa. Para tanto, contextualizamos a análise a partir da doença e suas metáforas, da literatura infanto-juvenil e da presença da temática da doença em tal literatura.

Palavras-chave: literatura infanto-juvenil, doença, narrativa

\begin{abstract}
In Western contemporary societies, illnesses are in the list of socially forbidden topics. This subject is seen as a taboo due to the meanings we attach to diseases and the diseased. Looking into the literature for children, we wonder how predicaments would appear in such literature. In this paper we look back on this topic, analyzing four literary works for children and youngsters published in Brazil that present the disease as their common narrative thread. In order to do that, we place in context the analysis starting from illnesses and their metaphors, from literary works, and from the presence of this subject in such literature.
\end{abstract}

Keywords: literature for children and youngsters, illness, narrative.

\footnotetext{
* Professora titular aposentada da Faculdade de Educação da UFRGS; atualmente, é professora permanente convidada do PPGEducação na mesma unidade. É bolsista de produtividade em pesquisa do $\mathrm{CNPq}$, desenvolvendo atualmente o projeto "Percursos e representações da infância em livros para crianças- um estudo de obras e de leituras", que conta com pesquisadores de várias universidades. É coordenadora do NECCSO, Núcleo de Estudos sobre Currículo, Cultura e Sociedade, grupo de pesquisa sediado no PPGEducação da Ufrgs, fundado em 1996.

** Doutoranda em Educação na Faculdade de Educação da Universidade Federal do Rio Grande do Sul, mestre em Comunicação Social (PUCRS).
} 


\section{ontextualizando o estudo - a doença, suas metáforas e a literatura}

A presença da doença como tema na literatura ou de personagens com doenças crônicas ou eventuais não constitui propriamente uma novidade no campo literário. De clássicos ficcionais como o romance $A$ Peste de Camus, às biografias ficcionais de Caio Fernando Abreu (como os contos publicados em Ovelhas Negras, livro assumido pelo autor como sua biografia, (BESSA, 2002, p. 131), as doenças e os doentes figuram na literatura mundial como tema principal em muitas obras. Isso, quando falamos da literatura não-adjetivada, ou seja, daquela que se entende como voltada para o público adulto. Mas, dadas as inegáveis peculiaridades com as quais é marcada a literatura destinada ao público infanto-juvenil, como as doenças apareceriam em tal literatura? É sobre essa temática que nos debruçaremos no presente trabalho, no qual efetuamos a análise de quatro obras literárias infanto-juvenis disponíveis no mercado brasileiro, que trazem a doença como fio condutor da narrativa. Não se tem a intenção, entretanto, de esmiuçar questões relativas à forma e/ou estética literária, detendo-nos, isso sim, numa análise temática das representações associadas à doença nos textos.

Independentemente do sentido que damos às doenças, convivemos e sempre conviveremos com elas. Adultos, crianças, jovens, idosos, todos passamos pela experiência da doença, seja no nosso próprio corpo, seja nos corpos de nossos entes próximos, seja por momentos breves, seja por longos períodos. No entanto, falar sobre a doença na sociedade ocidental contemporânea é um tabu. Isso acontece em função dos sentidos que atribuímos às doenças e aos doentes. No século XX, com o avanço do conhecimento médico, com a medicalização da população e a expansão das medidas preventivas de doenças, exibir a doença ou falar sobre ela tornou-se, de certa forma, inadmissível em nome da decência: "o corpo é o lugar onde a pessoa deve esforçar-se para parecer que vai bem de saúde" (MOULIN, 2003, p. 19-20). Esse discurso acabou por propagar o que Moulin, analisando o corpo frente à medicina, na obra $A$ História do Corpo, afirma, ao chamar de mal do século a solidão, principalmente a dos doentes, "aqueles a quem de ora em diante compete decidir sobre a sorte de um corpo que não se assemelha a nenhum outro" (Moulin, 2003, p. 53). Assim, na sociedade do imperativo do corpo saudável, a doença encontra-se deslocada. Se, no século XIX, a "literatura da tuberculose" (tendo A montanha mágica de Thomas Mann como 
exemplo central) tem uma grande difusão e a figura da pessoa com tuberculose, melancólica, tem uma aura de sedução e profundidade - Sontag afirma que "ser tuberculoso já havia adquirido a conotação de ser romântico em meados do século XVIII" (SONTAG, 2007, p.29) - representando algo até mesmo desejado, no século XXI, parece que é o sujeito fitness e esbanjando saúde que deveria ser lembrado, exaltado e narrado.

Assim, a identidade ligada ao sujeito doente é rechaçada a todo custo. E isso, como explica Sontag em Doença como metáfora (2007), acontece devido às metáforas criadas para as doenças. Falar sobre doenças é, sempre, falar sobre os sentidos que damos a elas. Apresentar um personagem com certo tipo de doença é evocar um determinado tipo de sujeito. Isso, porque as doenças carregam consigo seus significados históricos e culturais. Assim, quando falamos de uma doença sexualmente transmissível, por exemplo, remetemos a certo tipo de comportamento sexual considerado impróprio. Sobre essas metáforas e sentidos, Sontag traz também o exemplo do câncer como uma doença que carrega consigo a metáfora da culpa do doente, uma vez que foi construída, socialmente, a ideia de que os cânceres são causados por mágoas mal resolvidas do sujeito. Assim, quando referimos que uma dada pessoa tem câncer, tal fato suscita a associação com a imagem de uma pessoa ou rancorosa, ou que teria sido incapaz de extravasar "suas dores da alma".

Todas as doenças, até mesmo as mais comuns, se associam a metáforas que são carregadas de fantasias e imaginários próprios. Não falamos apenas de seu caráter biológico e de seus sintomas, mas também do que projetamos quando enunciamos o nome dessa doença, de quais medos, ansiedades, fobias projetamos junto a ela. Para Sontag (2007), as doenças são comumente associadas a alguma deformação moral e, por vezes, à pobreza, principalmente as doenças endêmicas e contagiosas. Segundo a autora, no século XIX, com a assunção da consciência individual da doença, a saúde era um sinal de virtude e a doença, de depravação. No entanto, não podemos nos esquecer das "vítimas inocentes", ou seja, das crianças com doenças. Como as doenças ainda carregam, em largos segmentos da nossa sociedade, uma associação a castigo divino, as crianças, que nada teriam feito de "errado" ainda nessa vida, são consideradas vítimas inocentes ou, ainda, no campo religioso, missionárias que vieram ensinar algo a partir de seus sofrimentos. 
Nos dias atuais, pode-se observar que quase todas as doenças que não são de contágio direto são consideradas como tendo um componente psicossomático ou comportamental. Tais origens colocam a culpa da doença no próprio doente. No caso das doenças contagiosas, poderiam ser evitadas com comportamentos considerados mais seguros. Já as doenças psicossomáticas, assim como as comportamentais, poderiam ser contidas com a adoção de um estilo de vida considerado mais saudável. Todos somos convocados à prática regular de exercícios físicos, à alimentação saudável etc. como forma de prevenção de toda e qualquer doença. Ou, como nos elucidam Guerrero e Bouzaglo (2009), toda doença é evocada como tendo uma condição contagiosa, porque traz consigo os medos (sexuais, raciais, políticos) do corpo. O enfermo, pois, vive em oposição ao saudável, considerado normal (GUERRERO e BOUZAGLO 2009, p. 23).

Doença como culpa, doença como castigo, doença como falta, doença como ausência de saúde. Seja no discurso social, seja no discurso biomédico, as doenças e os diagnósticos carregam consigo julgamentos morais. As metáforas das doenças são resultado desses julgamentos. O corpo doente é o corpo indesejado, que, do ponto de vista biomédico, precisa ser curado, precisa entrar em harmonia e voltar a ter saúde; do ponto de vista social, é inadequado e perigoso e, para falarmos de contextos do neocapitalismo em que vivemos, é o corpo que traz prejuízos econômicos, não produz e apenas acarreta despesas.

Dessa forma, a doença, ao modificar o corpo e a forma de o sujeito estar no mundo, muda os seus lugares, fazendo do doente um nômade indesejável que busca seu lugar, mas não é orientado para onde deve ir. Solomon (2013) observa que deveríamos criar outras metáforas, atribuir outros sentidos às experiências de doença, uma vez que vivemos e viveremos com elas sempre. O autor explica que "usamos o termo 'doença' para depreciar um modo de ser, e 'identidade' para validar a mesma maneira de ser. [...] Muitas condições são tanto doença como identidade, mas só podemos ver uma se obscurecermos a outra. [...] Precisamos de um vocabulário em que os dois conceitos não sejam opostos, mas aspectos compatíveis de uma condição" (SOLOMON, 2013, p. 15).

Talvez esse novo vocabulário possa vir de um campo que pode abordar abertamente a doença, por estar "protegido" sob a égide da ficção: a literatura. 0 campo literário conta com uma "licença ou álibi ficcional" para falar abertamente sobre as doenças e suas metáforas e, até mesmo, criar novas. Além disso, as narrativas literárias descrevem dramas individuais, em que a experiência do 
sujeito doente ou que convive com a doença pode ser abertamente explorada, sem necessariamente ter que "pedir licença" para se colocar no espaço público, nem sofrer os constrangimentos das "pessoas reais".

Sontag (2007) destaca, em seu trabalho, alguns personagens da literatura clássica que mostram o ser humano numa situação extrema e, portanto, vulnerável, buscando resgatar no seu íntimo o que tem de melhor e pior; assim, a doença vem como uma redenção. Desnecessário lembrar que o texto literário não deve ser entendido num sentido literal, na medida em que "cria o estado de coisas ao qual se refere [já que] a linguagem literária é performativa e uma elocução performativa não é verdadeira ou falsa" (CULLER, 1999, p. 97). Deixemos a ilusão de real para a narrativa biomédica, que se apresenta como objetiva e isenta. O que nos interessa aqui é que a literatura, seja ela de ficção, poética ou de cunho mais (auto)biográfico, cria um campo de experiência compartilhada entre obra e leitores.

Ainda lembrando algumas das metáforas mais comuns das doenças, temos a metáfora militar, que vê o corpo como espaço de luta, espaço invadido que precisa se livrar do seu invasor. Não é raro vermos pessoas com doenças serem chamadas de guerreiras ou a menção à morte como a "perder a guerra contra $X^{\prime \prime}$. Já a metáfora do estrangeiro, desse outro que invade o corpo alheio e de que a doença sempre vem do exterior é mais utilizada nas doenças infectocontagiosas. $\mathrm{O}$ outro é o perigo. Existem ainda outros aspectos que acompanham a ideia de doença, como a perda, a morte, a fragilidade e a decomposição, muito associadas não só às perdas físicas, mas também às sociais. Além disso, a vergonha e a culpa são características comuns a todas as doenças. Como podemos perceber, as metáforas sobre as doenças têm sempre aspectos majoritariamente negativos e os referenciais que associamos às doenças, também.

\section{Doença e livros para crianças e jovens - breve notícia}

É pouco copiosa a bibliografia sobre a presença da doença ou de personagens doentes na literatura infanto-juvenil, talvez refletindo uma relativa escassez de obras sobre o tema, considerando ser essa literatura um tanto refratária a temas que não possam ser resolvidos, num enredo, com um final feliz. Num dos raros trabalhos que, ao analisar personagens infantis com deficiência, também 
abrange aquelas que possuem doenças graves, das quais ora se recuperam, ora não, Dowker (2013) examina personagens com deficiência (e alguns, com doenças crônicas) em livros britânicos e norte-americanos do século XIX ao início do século XXI. Evidenciando como a literatura infantil está fortemente ligada às imagens de criança leitora e às representações e concepções dominantes nos diferentes contextos sociais em que é produzida, Dowker observa que "a literatura infantil do século XIX frequentemente enfatiza que infortúnios aparentes devem ser aceitos como parte de um plano superior" (DOWKER, 2013, p. 5), ou seja, tais infortúnios, incluindo as doenças, fariam parte do que a autora chama de "Escola do Sofrimento", na qual se exerceria uma disciplina espiritual, "propiciada" pelos desígnios divinos, que levaria as personagens a seu aperfeiçoamento, através da aceitação das dores e limitações, do exercício da paciência etc. Afirma a autora: “(...) para os escritores do século XIX, a aceitação de uma saúde frágil e da deficiência, assim como de outros infortúnios, frequentemente era vista como parte da aprendizagem em aceitar a vontade de Deus com relação a todos os aspectos da vida" (DOWKER, 2013, p. 5).

Em outro artigo, Silveira, Bonin e Ripoll (2013) dedicam-se à análise de dez obras voltadas para crianças que abordam especificamente a questão da doença na velhice (quase sempre em personagens avós) e o relacionamento dos pequenos com as modificações que enfermidades como Alzheimer, Parkinson, ocorrência de AVC, frequentemente trazem aos mais velhos. Embora se trate de dez títulos disponíveis no mercado brasileiro recente, nove deles são traduções de edições estrangeiras, publicadas em países onde o envelhecimento da população - anterior ao que hoje se processa no Brasil - certamente gerou preocupações, reavivando a tradicional vocação pedagógica dos livros para crianças. Efetivamente, apesar de uma diferença de maior ou menor investimento no uso de recursos ficcionais e estéticos, a análise do conjunto das dez obras mostrou como a criança leitora vai sendo ensinada - através de uma possível identificação com as protagonistas infantis dos livros - a lidar com situações decorrentes de doenças que atingem um avô ou avó. Afirmam as autoras que "as obras analisadas posicionam as personagens crianças a partir de atos solidários, afetuosos e/ou interessados em entender o que se passa com os avós. Elas participam no cuidado dos velhos doentes ou devem ser protegidas e resguardadas de situações consideradas inadequadas para a infância" (SILVEIRA, BONIN e RIPOLL, 2013, p. 11). 
A maior quantidade de trabalhos que associam doença e literatura infantil, entretanto, volta-se para o uso da literatura no campo da chamada biblioterapia, que utiliza a literatura como forma de terapia para crianças (e outros sujeitos) que têm ou convivem com alguma doença. A leitura de uma revisão bibliográfica sobre ações mais recentes de biblioterapia no Brasil, como a realizada por Sousa, Santos e Ramos (2013), mostra uma dispersão de intenções, públicos e materiais utilizados, incluindo, em alguns casos, a utilização de livros e manuais escritos para que as crianças e jovens "entendam" a doença com a qual convivem. No entanto, esses estudos nem sempre privilegiam livros com efetivo viés literário, além de se voltarem para o objetivo pedagógico e terapêutico da leitura e da escrita, motivo pelo qual não nos deteremos neste campo. Especificamente, nos debruçaremos sobre quatro obras voltadas para adolescentes brasileiros, publicadas de 1980 a 2014: O empinador de estrela ([1980] 2013), Brenda (2014), A caixa de Klara ([2008] 2014), Íris, uma despedida ([1992] 2012); as duas primeiras são de autores brasileiros e as duas últimas, de autores estrangeiros (sendo que três edições foram ilustradas por ilustradores brasileiros e uma, por uma ilustradora espanhola); todas elas tomam a doença como tema central.

Entendemos que a publicação e disponibilização desses livros relacionam-se com o que Colomer (2003) constatou, a partir do exame de um vasto acervo da literatura infantil mais recente. A autora espanhola, ao examinar a incorporação de temáticas que tradicionalmente não frequentavam a literatura para crianças e jovens, tais como diferenças sociais, deficiência, novas configurações familiares etc., localiza tal movimento a partir dos anos sessenta e setenta do século $X X$, afirmando:

Os livros dirigidos às crianças tiveram que variar seus temas, tanto para refletir os problemas e formas de vida próprios da realidade dos leitores, como para responder à preocupação educativa que, fruto de novas atitudes morais, debilitava o consenso sobre a preservação da infância como uma etapa inocente e incontaminada, própria da narrativa das décadas anteriores. (COLOMER, 2003, p. 257) 


\section{Conhecendo e analisando as obras}

Obra de lançamento mais recuado dentre os quatro livros em análise, $O \mathrm{Em}$ pinador de Estrela, de Lourenço Diaféria, teve sua 1a edição em 1980, mas continuou sendo editado com alguma regularidade desde então. No livro, narrado em 1a pessoa por um menino que mora em uma pequena cidade brasileira interiorana, o autor recria um ambiente que, a nós, leitores da segunda década do século XXI, soa como idílico, mobilizando elementos daquela época e contexto. Eduardo, o menino protagonista, mescla episódios e vivências da sua meninice, como a relação próxima com elementos da natureza, como uma lagarta, uma formiga, a camaradagem e o interesse pelos jogos de futebol de várzea, vivências escolares, cenas familiares e trocas entre vizinhos, amigos, compadres, com o desenrolar de fatos que decorrem dum acontecimento perturbador de sua vida - a descoberta de que o pai está doente e as mudanças que tal evento desencadeia na vida familiar e no círculo mais próximo. Aos questionamentos sobre a doença do pai, apenas obtém as respostas evasivas que os adultos costumam conceder às crianças, de tal forma que os sentimentos que o protagonista experimenta - quando o pai vai se internar em uma cidade para fazer uma cirurgia, sendo acompanhado por sua mãe, o que significa que o menino ficará em companhia de uma familiar substituta - são de preocupação, tristeza - pela perda da convivência -e temor.

Num tempo em que as notícias chegavam às pequenas cidades do interior através de uma central telefônica ou através dos caminhoneiros que faziam o trânsito entre os lugarejos, de súbito, o menino é surpreendido pela notícia trazida pelo chofer de caminhão Tibúrcio, que grita para sua tia: " - Dona Nhanhá, o homem é uma lasca de peroba! Abriram ele daqui até aqui, e já acordou pedindo arroz e feijão!" (DIAFÉRIA, 2013, p. 50). Esfuziante de alegria, o protagonista começa a elaborar várias hipóteses sobre como tudo voltaria ao cotidiano anterior, de antes da doença paterna, e, querendo expressar de maneira inusitada e pública sua alegria, dedica-se a fazer a mais bela pipa que consegue, em forma de estrela, com todos os detalhes de uma pipa tradicional, a qual atrai os olhares e arranca elogios variados das pessoas da pequena cidade. Ainda que rica em detalhes que caracterizam o cenário onde decorrem as ações - o quintal onde o menino brincava, os objetos que faziam parte do dia-a-dia, como o rádio sobre a prateleira da sala, os costumes interioranos, como o futebol de várzea, a liber- 
dade de as crianças circularem pelo bairro, a narrativa é econômica na exposição dos sentimentos do narrador menino.

Assim, a relação do protagonista com a realidade das dores e aflições da doença do pai é bastante distanciada, de certa forma seguindo uma das tendências frequentes em nossa sociedade: a de manter as crianças afastadas de assuntos dolorosos. E, de forma consistente com o ponto de vista do narrador menino, não há detalhes sobre a doença nem sobre o tratamento do pai (que se desenrola numa cidade grande, enquanto o menino fica na cidadezinha), mas uma exploração de suas reflexões de criança, iluminadas pela notícia da operação bem sucedida do pai, que o motivaram a fazer uma pipa "caprichada", como uma forma de comunicar a todos sua alegria, considerando seus pensamentos anteriores:

Como é que eu podia dizer a todo mundo da cidade que o Tibúrcio tinha chegado com a cara barbuda dele, e levantado o polegar, e que meu pai era um pedaço de peroba de força e resistência, e que ele voltaria a jogar dominó com os amigos, e tornaria a consertar o muro descascado, e novamente iria me cortar o coto de pão, me daria o bule de café, e perguntaria como eu ia de lição na escola, e fumaria seus cigarrinhos, essas coisas simples de todos os dias, de que a gente tem saudades quando elas acabam? (DIAFÉRIA, 2013, p. 53)

Obra escrita pela autora alemã Gudrun Mebs, originalmente publicada em 1992 e editada no Brasil em 2012, Íris, uma despedida, traz uma narrativa pungente, em primeira pessoa, de uma menina cuja irmã mais velha - Íris - é diagnosticada com um tumor no cérebro e, num curto espaço de tempo, embora submetida à cirurgia e tratamento, acaba morrendo. A reconstrução da voz da criança, com suas curiosidades, dúvidas e elaborações próprias das informações e pistas que os adultos Ihe oferecem, é meticulosa e consistente. Diferentemente da primeira obra analisada, aqui as informações vão sendo dadas de forma mais direta à personagem menina, como uma espécie de preparação para o que poderia vir. "Ele [o papai] contou que a Íris estava muito doente, que o médico tinha falado isso (...) e que a Íris podia morrer" (MEBS, 2012, p. 8). Assim, ao saber que sua irmã tinha câncer, a pequena narradora vai procurar o significado da palavra no dicionário; no decorrer de todos os capítulos, ela vai tentando integrar todos os acontecimentos novos - a cirurgia da irmã, a visita ao hospital, 
o respeito e a consideração que passa a receber na escola - às mudanças do seu cotidiano (a ausência da mãe, a tristeza do pai, as atenções da avó), mas, principalmente, às mudanças ocasionadas pela ausência da irmã no mesmo quarto. $E$, embora se lembrando que, assim, não precisava mais ouvir os roncos da irmã, vai experimentando as dores dessa separação: "E agora ninguém ronca mais à noite. Eu queria que a Íris voltasse” (MEBS, 2012, p. 20). Num gesto de fraternidade, ela lembra como a irmã sempre dorme com seu carneirinho e pede para seu pai levá-lo para o hospital.

A frequência com que a pequena narradora menciona o choro dos pais, o relato de sua breve visita à irmã, onde é surpreendida com a falta de cabelo dela, e a citação da forma como vão comunicando a piora progressiva da irmã pontuam o relato com doses de realismo: "E ele disse que o tipo de câncer da Íris não vai embora assim de uma vez, que a esperança é pequena" (MEBS, 2012, p. 33); "Ele disse que a Íris não consegue engolir nada e por isso precisa ser alimentada artificialmente" (MEBS, 2012, p. 57); “À noite, ele ligou pra vovó (...) e disse que a Íris não conseguia mais respirar direito. (...) E disse que agora tudo seria muito rápido. Mas ele não disse o que seria muito rápido" (MEBS, 2012, p. 61); "Então, ela [a vovó] se virou pra mim e disse: "A Íris morreu nesta noite" (MEBS, 2012, p. 63-64). Entretanto, com cada uma das informações trazidas pelos adultos, a pequena narradora tece uma série de associações, buscando completar as lacunas das falas dos adultos e compreender o que os fatos trariam associados a si como desdobramentos. Todo este mosaico de reflexões, sentimentos e perplexidade torna-se mais agudo nas páginas em que a menina busca entender, a partir das diferentes falas dos familiares, o que seria a morte da irmã: um corpo que morre e é enterrado e uma alma que voa? Morrer é dormir? A alma da irmã pode vê-la? Mesmo sem ver a irmã, poderá sentir a presença dela? Mas é preciso se concentrar para que isso aconteça? E a obra termina com a referência de que a narradora ainda está tricotando um chapeuzinho azul para a irmã (que tinha ficado careca) e o seu pensamento: "Pode ser que a Íris me conte (quando eu conseguir sentir a presença dela) que gostou do chapeuzinho e que ficou feliz" (MEBS, 2012, p. 76).

Observem-se, ainda, a delicadeza e a simbologia das ilustrações do livro, mostrando a doença em forma de flores e pétalas azuis, que vão crescendo e se apoderando do corpo e da cabeça de Íris, numa narrativa imagética que aponta a progressiva fragilização da menina até a morte, quando só restam as pétalas. 
Tematizando uma doença grave, terminal, vivenciada de perto por uma turma de crianças, mas em situação bastante diversa da trazida nas obras anteriores, temos o livro A caixa de Klara, escrito por Rachel Kooij, em 2008, e traduzido no Brasil em 2014. A situação inicial da obra já é inusitada - a professora de um quarto ano, tendo sido acometida de um câncer agressivo, sem efetivos resultados no tratamento, resolve ir, simplesmente, à escola, acompanhar a sua turma mais um semestre, ocupando um cantinho da classe: "- Por isso, eu me despedi do hospital - diz ela, hesitando um pouco. - Para viver de verdade por mais um tempo com vocês, se vocês quiserem" (KOOIJ, 2014, p. 15). Os primeiros sentimentos das crianças são de inconformidade, incompreensão e revolta frente à doença da professora, traduzida em choro, mas esta consegue, transfigurando a situação, sentar-se no fundo da sala em uma espreguiçadeira numa condição ficcional de "estar na praia", vendo "seus peixes", "descansando à beira-mar", quebrar o clima funéreo, num jogo mágico em que as crianças também se engajam.

Obviamente - e a autora é bem sucedida no aproveitamento ficcional de tal aspecto - essa quebra das regras contemporâneas sobre doenças terminais e morte, que prescrevem o isolamento do sujeito nessa situação, suscita vívidas reações da mãe de um aluno, que manifesta a preocupação em preservar o filho da dor de vivenciar de perto a agonia e a morte de uma pessoa que ama. Por outro lado, toda a situação fictícia de uma praia no fundo da sala, com a professora doente acompanhando seus alunos, é enriquecida pela imaginação dos alunos, embora a trama se abra para os seus sentimentos conflitantes e preocupações, em especial das personagens Julius e Elena, sobre o desfecho da situação. Muitos acontecimentos, conflitos e negociações são vividos pela turminha e pela professora, como a discussão sobre a possibilidade de um milagre e sobre "quem mereceria um milagre"; evidentemente, o milagre desejado pelas crianças é a cura da professora; mas esta afirma que "dá de presente" o milagre almejado para alguma criança que esteja em um perigo iminente (o que não tarda a acontecer). Mas o semestre chega ao fim e a progressiva debilitação da saúde da professora é visível - ela se despede da turma. E é através de vários diálogos e conversas das crianças, que seus sentimentos controversos, seus temores, suas curiosidades e especulações vão se confrontando e se mostrando. Múltiplas reflexões povoam a mente de Julius, um dos protagonistas: sobre a morte, sobre vida após a morte, sobre a existência de um céu, sobre a possibilidade de reencontro após a morte. Outros elementos do progressivo definhamento 
da professora e dos cuidados especiais que ela passa a necessitar são visualizados pelo menino - a cama hospitalar, o soro, o balão de oxigênio - quando Julius acaba por visitá-la. Observe-se que, à medida que episódios do cotidiano das crianças são trazidos, o narrador apresenta elementos que, de certa forma, prefiguram o desfecho da história: esse é caso da narrativa sobre o enterro do hamster de Elena e da ecografia da irmã de Julius. Uma das situações de difícil resolução pelos alunos é a da escolha do presente que dariam para a querida mestra - o livro sobre atrações turísticas que haviam comprado no ano anterior já não Ihes parece adequado. E é a partir de um sonho de Julius e de conversas com Elena, que resolvem: "Nosso presente vai ser uma caixa. Colorida, bonita e original, fora do comum. Ela precisa, pelo menos, não ter mais medo da caixa preta" (KOOIJ, 2014, p. 76-7).

Auxiliados pelo avô de Julius, velho marceneiro, eles decoram a "caixa de Klara", ou seja, um colorido caixão, com desenhos, pinturas, recortes e colagens tornando presentes muitos elementos que marcaram sua feliz e imaginativa convivência com a professora. Obviamente, mais uma vez essa "ideia fora do lugar" é descoberta e a finalização da caixa e sua entrega é quase impedida pelos adultos, que a julgam descabida e de mau gosto. Entretanto, com a cumplicidade do avô, a turminha consegue levar a "caixa de Klara" pelas ruas da pequena cidade, numa jornada que também é entremeada por brincadeiras e corridas - de certa forma, demonstrando o quanto alegria, vida e morte podem se mesclar no cotidiano. As crianças acabam por entregá-la para o marido da professora, que a acompanha em suas últimas horas de vida. E este "fica feliz por poder Ihe contar o que seus alunos construíram para ela (...) E enquanto ele descreve a caixa para sua Klarinha, nos mínimos detalhes, ela fecha os olhos, sorrindo, e nunca mais os abre" (KOOIJ, 2014, p. 234).

Brenda, de Luiz Antonio Aguiar, é a narrativa mais recente entre as obras analisadas, tendo sido publicada pela primeira vez em 2014. A obra articula elementos da literatura fantástica, mobilizados pela presença de uma personagem tradicional do universo fantástico - um lobisomem mulher ou licantropa - com uma situação limite inspirada na realidade: um jovem com câncer em estágio avançado. $\mathrm{O}$ autor nos traz a história de dois irmãos gêmeos, um dos quais está com câncer e está em tratamento (Pepeu), mas a voz narrativa em primeira pessoa é do outro irmão saudável, Lico (e aí já há um jogo com a palavra grega que nomeia "lobo"). Lico sofre com a situação em que Pepeu se encontra e com as 
mudanças ocorridas no cotidiano familiar em função da doença e do tratamento do irmão. Uma das vertentes da narrativa justamente focaliza essa problemática. Como, em função de Pepeu fazer seu tratamento longe de casa, na capital, Lico passou muito tempo sem ver o irmão, quando este volta, bastante debilitado, da primeira fase de um tratamento quimioterápico, fica chocado ao vê-lo tão fragilizado: "o que via à minha frente era uma versão cadavérica de mim mesmo" (AGUIAR, 2014, p.22). E as mudanças não estavam apenas no corpo físico, como observa: "O coração de Pepeu havia envelhecido. Nisso, me deixara para trás. E acontecera naqueles dois meses" (AGUIAR, 2014, p. 22).

Outra vertente da narrativa - e essa duplicidade de desenvolvimento do enredo tem como elemento comum o protagonista Lico - inicia-se com o primeiro encontro deste com uma menina desconhecida, Brenda, com quem passa a se encontrar com frequência, sempre à noite. Brenda é uma menina diferente, de poucas palavras, cujas atitudes e desconcertantes aparecimentos e desaparecimentos desorientam o rapaz. Progressivamente, através de elementos variados, o autor vai dando pistas sobre a identidade sobrenatural da moça. Observe-se que Lico narra a ela passagens de sua convivência diária com a família, o irmão e sua doença. Além de descrever fisicamente o irmão, o tubo de oxigênio que o auxilia a respirar, sua falta de fôlego até mesmo para conversar, também menciona como se fala pouco sobre a doença na casa:

Ninguém entendia direito o que estava acontecendo. Como se um monstro, um ogro, tivesse arrombado a porta e invadisse a casa, quebrando tudo, sem se importar de nos dar explicações de por que estava demolindo a vida da gente. E o pior era que a gente não conversava. O ogro seguia arrebentando tudo. E ninguém dizia sequer algo como: Já notou que a pele dele é esverdeada? Que a língua é amarela e que ele tem chifres? Ora, bem que a gente poderia se falar de vez em quando para comentar o assunto, só pra mostrar que estava vendo o ogro fazer essas coisas. (AGUIAR, 2014, p. 28)

A utilização da metáfora do monstro que adentra a casa, tudo invadindo e destruindo, sem que, no entanto, ninguém fale sobre ele, confere vivacidade ao relato. E o narrador prossegue, tematizando o quanto não falar sobre o assunto o incomodava: 
Acho que ninguém ali tinha força pra aguentar aquela barra. E, no entanto, tinha de continuar vivendo. Acordar, tomar café da manhã etc. Todos os dias. Porque pouca coisa muda fora da gente, quando por dentro está doendo. Mesmo que esteja doendo de matar. Pouca coisa muda,um dia depois do outro, e parece que tudo está como era antes. Como foi. Não como pode deixar de ser. Não me lembro de ter escutado deles, uma vez sequer, a palavra câncer [...] Mas era assim, a gente fazia da doença do Pepeu uma coisa que ninguém conseguiria imaginar. $\mathrm{E}$ a verdade também é que eu fazia parte desse circo. Eu tinha meu papel, meu número, e o representava, assim como eles. (AGUIAR, 2014, p. 30)

É interessante observar, nessa narrativa (e não na anterior, por exemplo), a representação do acordo tácito de que não se deve falar sobre uma doença em curso, de acordo com a crença social de que falar sobre a doença a chama ou a fortalece (SONTAG, 2007); isso está muito presente na narrativa de Lico, que confessa nem saber por que não se fala sobre o assunto. Também com o irmão, ele tinha medo de falar sobre a doença, mas Pepeu o procurava para conversar, como no dia em que confessa estar com medo de morrer, desencadeando um diálogo em que os dois expõem seus temores. Também a busca de entendimento do porquê da situação é tema de suas conversas; numa delas, Lico diz que tenta entender por que essa doença, por que com Pepeu, ao que o irmão responde: "Sabe... Acho que não dá para entender... por quê... Eu já tentei muito. Desisti porque... não dá mesmo. Então, fico com vontade de chutar tudo. E todo mundo, daí paro e... só paro. Sem fôlego. Não tem um porquê. Não tem, sabe?" (AGUIAR, 2014, p. 86).

As duas vertentes da narrativa vão se entrelaçando; por um lado, Lico continuava se encontrando com Brenda, a qual ele estava cada vez mais convencido que era um lobisomem, ou melhor, uma lobismulher, ou, como ela preferia, uma licantropa. Ao pesquisar sobre lobisomens na internet, ele descobre que os lobisomens teriam capacidade de curar qualquer doença ou ferimento. Nessa articulação de faces de sua vida, Lico faz uma espécie de acordo com Brenda: em uma noite de lua cheia, ouve-a uivar e deixa a porta de casa aberta, para que ela, em sua forma animal, possa entrar, arranhar Pepeu e lamber o ferimento. Após essa noite, Pepeu começa a se recuperar, e os dois irmãos vão para a capital um, para prosseguir o tratamento e o outro, talvez por temer que fosse cobrada a sua parte no acordo feito com Brenda. 
Um ano depois, Pepeu se encontra em remissão, como explica Lico: "Remissão, é assim que os médicos falam, quando o caso é câncer. Eles não fecham o problema, não dão descanso. Não é culpa deles, é dessa droga de doença. Tem de manter o estado de alerta, luz amarela ligada". (AGUIAR, 2014, p. 122). Para comemorar, Pepeu quer voltar à cidade deles, e é nessa ocasião que Lico acaba por se encontrar com Brenda, que se transforma em lobo (de acordo com toda a mitologia sobre lobisomens em noites de lua cheia) e ele não consegue fugir. Cai no chão, debate-se e, quando acorda, descobre que o irmão o encontrou no meio do matagal, arranhando-se, gritando e que ele ardera em febre por muitos dias.

Sem saber se o que vivera fora realidade, alucinação ou a repercussão de um trauma pessoal, em função de todos os sofrimentos pelos quais a família passara, Lico reflete: "meu irmão chegou muito perto de morrer de câncer. Meu irmão gêmeo. Sempre foi como se eu morresse também. Se ele morresse, como eu ia acreditar que continuaria vivo? Seria uma alucinação quase como... Brenda" (AGUIAR, 2014 ,p. 150). Mas Lico (e a construção do relato, através da sua voz, deixa em aberto o final) continuava com suas dúvidas sobre a invenção (ou não) de Brenda, nem sabia se o que tinha curado o irmão, ou o colocado em remissão, como diziam os médicos, teria sido o tratamento médico ou a ação dos poderes sobrenaturais de Brenda, a licantropa.

E é com essa narrativa fantástica - ou de terror, como o próprio Aguiar a nomeia num paratexto - que o autor fala do câncer, do medo da morte e do tabu que é falar sobre a doença, mesmo em um meio que convive com ela, como é o caso da família do personagem-narrador.

\section{Fechando as pontas}

Findo este breve percurso analítico, a primeira impressão que construímos é a de que, progressivamente, a literatura infanto-juvenil tem se aberto para o difícil tema da doença grave e para todo o leque de sentimentos, consequências, representações e metáforas a ela associado, sem dar as costas para o repertório de recursos literários de que os autores podem se valer. Assim, se no livro de publicação mais recuada, apenas o substantivo "doença" e o adjetivo "doente" estão presentes, e o enfoque é dado principalmente aos sentimentos do meni- 
no frente às notícias que chegam sobre o pai, as três obras mais recentes, de diferentes autores, não se furtam a apontar o nome da doença ("câncer") e nem fogem de algumas caracterizações dos efeitos físicos e do sofrimento trazidos pela doença, não só aos doentes, mas aos familiares.

Mesmo transfiguradas pela roupagem literária, dotadas de originalidade, as obras, entretanto, não deixam de se alimentar das metáforas e das referências circulantes sobre a doença. Assim é que, em três delas, o isolamento - no hospital, na cidade onde há um melhor tratamento - é um traço que marca a vida do doente. E, paradoxalmente, em A caixa de Klara, é a recusa ao isolamento por parte da professora doente que provoca o repúdio dos familiares das crianças. Para a mãe de Julius, um dos alunos, Klara deveria ficar isolada, poupando as crianças de sua visão. Esse embate entre ideias tradicionais do mundo adulto, de escamoteamento da presença dos doentes terminais e dos próprios sinais da morte (parece absurdo aos adultos que as crianças queiram dar à professora um caixão decorado com as lembranças comuns!) e, por outro lado, as novas disposições da professora doente e a adesão das crianças é uma das espinhas dorsais da novela.

Também em íris, uma despedida, a irmã menor é afastada pela possibilidade do contágio, no asséptico hospital e, após a morte de Íris, do enterro da irmã tão próxima. Por outro lado, todos os livros falam do medo - do medo da perda, da ausência da pessoa amada, do desconhecido. Não por acaso três deles trazem as reflexões e as dúvidas - vazadas em raciocínios mais ou menos adultos, conforme a idade dos personagens narradores - sobre a morte, multiplicadas pelas muitas respostas que secularmente vêm se dando à questão.

Observe-se, por fim, que nenhuma das obras se enquadraria nos livros de finalidade biblioterápica precípua, assim como nenhuma delas tem um caráter autobiográfico. Afinal, podemos pensar sobre o quanto todos os temas humanos podem integrar as obras para crianças, adolescentes e jovens. Morte, doença, diferenças, abandono, solidão fazem parte da nossa vida e sempre o farão. São inerentes ao ser humano e sua abordagem - em especial se transfigurada pelo tratamento literário - faz parte de nossa constituição como humanos.

Ainda que falem principalmente à sensibilidade de seus leitores e, de maneira articulada, possam trazer alguma informação desconhecida a eles, as quatro obras analisadas não têm cunho pedagógico, nem pretendem ensinar aos adolescentes o que fazer na convivência com doentes graves, nem sobre o que "efe- 
tivamente" aconteceria depois da morte. Lançando mão de recursos ficcionais (e a narrativa em 1a pessoa é um dos que pode conferir maior autenticidade e força aos relatos), de metáforas, do monólogo interior (como exemplificamos), de uma construção potente da voz infantil (como é o caso de Íris), da seleção de detalhes de cenário ou ação que conferirão significado especial à narrativa (como é o caso de A caixa de Klara), as novelas mostram inventividade e sensibilidade e se abrem literariamente a mais de uma leitura, desafiando o leitor a adentrar um mundo profundamente humano e complexo, que frequentemente Ihes é escamoteado, pelas narrativas e personagens vencedores, sempre sorridentes, felizes, saudáveis, movidos pela competição e ambição.

Face à leitura de tais obras, é impossível não nos perguntarmos, considerando justamente todas as representações contemporâneas sobre doenças e morte, e sobre a educação de nossos jovens alunos e filhos: mães, pais, professoras e professores julgarão adequado que tais narrativas cheguem às mãos dos adolescentes?

\section{Referências}

AGUIAR, Luiz Antonio. Brenda. Belo Horizonte: Dimensão, 2014.

BESSA, Marcelo Secron. Os Perigosos. Autobiografias e AIDS. Rio de Janeiro: Aeroplano, 2002.

COLOMER, Teresa. A formação do leitor literário: narrativa infantil e juvenil atual. São Paulo: Global, 2003.

CULLER, Jonathan. Teoria Literária. Uma Introdução. São Paulo: Beca Produções Culturais, 1999.

DIAFÉRIA, Lourenço. O empinador de estrela. São Paulo: Moderna, 2013.

DOWKER, Ann. A Representação da Deficiência em Livros Infantis: séculos XIX e XX. Educação \& Realidade, Porto Alegre, v. 38, n. 4, p. 1053-1068, out./dez. 2013. Disponível em http://seer.ufrgs.br/index.php/educacaoerealidade/article/view/38156/27748. Acesso em 10 nov. 2015.

GUERRERO, Javier; BOUZAGLO, Nathalie. Excesos del cuerpo: ficciones de contagio y enfermedad en América Latina. Buenos Aires: Eterna Cadencia, 2009.

KOOIJ, Rachel Van. A caixa de Klara. Tradução de Hedi Gnadinger. São Paulo: Edições SM, 2014.

MEBS, Gudrun; VIDAL, Beatriz Martín. Íris, uma despedida. Tradução de Daniel Bonomo.

São Paulo: Editora Pulo do Gato, 2012. 
MOULIN, Anne Marie. O corpo diante da medicina. In: COURBIN, Alain; COURTINE, Jean-Jacques; VIGARELLO, Georges. História do corpo. Vol.3. Petrópolis: Vozes, 2003.

SILVEIRA, Rosa Maria Hessel; BONIN, Iara Tatiana; RIPOLL, Daniela. (2013). Corpos velhos e doentes para crianças: uma análise de livros de literatura infantil. Nonada - Letras em Revista, v. 2, n.21. Disponível em: http://seer.uniritter.edu.br/index.php/nonada/ article/view/791/517. Acesso em 20 nov. 2015.

SOLOMON, Andrew. Longe da árvore. Pais, filhos e a busca da identidade. São Paulo: Companhia das Letras, 2013.

SONTAG, Susan. Doença como metáfora, AIDS e suas metáforas. São Paulo: Companhia das Letras, 2007.

SOUSA, Thais Caroline da Silva; SANTOS, Andréa Pereira, RAMOS, Rubem Borges Teixeira. Ações e projetos de biblioterapia: uma revisão de literatura brasileira. Anais do XXV Congresso Brasileiro de Biblioteconomia, Documento e Ciência da Informação Florianópolis, SC, Brasil, 07 a 10 de julho de 2013. Disponível em: http://portal.febab. org.br/anais/article/view/1500. Acesso em 10 nov.2015.

Submetido em: 30-11-2015 Aprovado para publicação: 04-08-2016 